\title{
Francophone Dynamics in a Translated Canada: From the Margins to the Centre and Back \\ Denise Merkle
}

\begin{abstract}
This paper examines French Acadian literature's at times conflicted relationship with the target language, English, the other official language of New Brunswick. A broad survey of Acadian literature since 1960 is punctuated with brief discussions of selected works in their sociopolitical context of production. Translations of these works can be placed variously on a continuum that ranges from extremes of vertical to horizontal translation. At one extreme, vertical translation homogenises a fractured identity into the dominant language through annexation. Alternatively, at the foreignising extreme, a translator may opt for a horizontal, minoritising, translation strategy in an effort to decentre the traditional power relationship between the two cultures. This paper gives an overview introduction to these strategies used to translate Acadian literature.
\end{abstract}

\section{Introduction}

Along with its reputation as a bilingual country, Canada is known throughout the world as a country of immigration and immigrants, and with (im)migration comes cultural and linguistic diversity. While today's multilingualism in such cities as Toronto, Montréal and Vancouver is impressively diverse, it must not be forgotten that Canada has a long history of multilingualism. The first French explorers exchanged with First Nations communities who spoke Iroquois, Huron and Cree, among other languages. The extent to which Canada's First Nations communities have been marginalised is generating mounting national and international concern. This paper will concentrate on another group that has been marginalised in Canada, although to a lesser extent than Canada's First Nations peoples: Canada's Acadian population. 
Canadian Francophone populations residing outside Québec have been marginalised not only by the majority Anglophone population, but also by Québécois. Marginalisation has resulted from their minority status in New Brunswick, Ontario, Manitoba, Saskatchewan and Alberta, among other provinces and territories, as well as from their geographical, and at times cultural, distance from Québec. Minority status results in frequent contact, and often friction, between the dominant and dominated languages and cultures (French versus English; varieties of Canadian French versus Québec French). Minority Francophones certainly feel the effects of frequent, if not constant, linguistic and cultural contact through linguistic and cultural hybridisation. Whereas in the past hybridisation was frowned upon and associated with assimilation, if not criticised outright, linguistic and cultural hybridisation has become fashionable of late thanks to the work of a number of postcolonial researchers, including Mary Louise Pratt (2007), Sherry Simon (1999) and Homi Bhabha (1994). Take as a case in point Acadians living in New Brunswick and to a lesser extent Nova Scotia, who now find themselves in a climate where their language varieties (Acadian French ${ }^{1}$ and Chiac $^{2}$ ) are valued in some circles as testimonials to their marginalised status and their search for a unique linguistic and cultural identity (Leclerc 2005). The value attributed to minor literatures ${ }^{3}$ and hybridisation has generated interest among members of dominant groups. Yet, in Canada, members of the dominant population are often unilingual or bilingual, even multilingual, without, however, French being one of their languages. Translation into and out of French therefore becomes a necessity, if one wishes to communicate with Canadian francophone communities (should, it must be underlined, the francophone communities accept the invitation ${ }^{4}$ ).

In the aim of providing a glimpse into the heavy weight of a fragile identity on the psyche of a minority population, this paper will examine a number of translation strategies (including editorial decisions) adopted by Canadian Anglophone translators who have taken up the challenge of translating Acadian literature into English. Some of the strategies do not reproduce the original's hybridisation, rather transforming the texts into "standard" Canadian English, whereas other innovative strategies attempt to create a hybrid form 
of English, thereby marginalising the target text. Should translation (process) by the dominant majority be accepted by the minority group, the product usually falls into one of two broad categories: vertical or horizontal translation (Merkle and Klimkiewicz 2008: 17). We shall consider the socio-cultural implications of efforts to move marginal literature to the centre through vertical translation into the "standard" dominant language versus efforts to decentre the target culture by transforming the target text through minoritising hybridisation of the dominant language. When a fractured identity is homogenised by the dominant language through the annexation of vertical translation, the "schizophrenic" angst felt by the translated people is invariably lost in translation. Cultural and linguistic differences have been overlooked. Put in other terms, Henri Meschonnic and Anthony Pym (2003) put the phenomenon in other terms and explain that "annexation is [...] an illusion of the natural, [...] as if the source-language text were written in the target language, overlooking the differences in culture [...] and in linguistic structure" (341). Alternatively, a translator may opt for a horizontal, minoritising, translation strategy, in an effort to decentre the traditional power relationship (Meschonnic 1973: 305-454) between the two cultures. The aim of a minoritising strategy is to unsettle a smug conceit shared by members of the dominant culture, thereby, shaking the latter's sense of immutable wholeness and giving it insights into the difficult existence of minority cultures. Meschonnic and Pym (2003) add that " $[d]$ ecentring is a textual relation between two texts in two language-cultures, [which extends] right to the linguistic structure of the language-system, this linguistic structure becoming value within the system of the text" (341).

Four canonical Acadian literary figures, who use language to special effect thereby demonstrating the linguistic varieties (i.e., multilingualism) within Acadie, will be the object of more detailed study after an initial contextualising discussion of Acadian poetry and translation. Whereas the first two poems that we will look at have not been translated, the works that are the object of detailed study have been. It is a pure coincidence that the four writers whose works have been translated are from Southeast New Brunswick with greater Moncton ${ }^{5}$ the region's epicentre, a region where French and 
English are in constant contact: Antonine Maillet (Bouctouche), Raymond (Guy) LeBlanc (St-Anselme, now part of Dieppe), Gérald Leblanc (Bouctouche) and France Daigle (Dieppe).

\section{Language Rights in New Brunswick}

In New Brunswick in the late sixties, Acadian youth contested the position of traditional Acadian elites who preferred to accommodate Anglophones, by among other things, not resisting assimilation (See Musée acadien, on line). Rather, young people chose to confront and denounce the conservatism and lack of transparency of these elites, and to create such cultural institutions as the publishing house, Les Éditions d'Acadie, in 1972. ${ }^{6}$ In the political arena, New Brunswick Premier Louis J. Robichaud was actively promoting a bilingual New Brunswick. Robichaud was the first Acadian premier of the province, elected to the office in 1960. His Liberal government established the only French-language university in New Brunswick in 1963, the Université de Moncton, located in the city of Moncton. As well, in 1963, Canadian Prime Minister Lester B. Pearson, concerned by the socio-cultural distance separating the country's English and French populations, had a royal commission created to examine bilingualism and biculturalism in the country. In 1967, the Laurendeau-Dunton commission recommended that the federal government pass an official languages law and that Canada's capital city, Ottawa, as well as the provinces of Ontario and New Brunswick, become officially bilingual. Only New Brunswick, under the direction of Robichaud, took up the challenge, enacting the Official Languages of New Brunswick Act in 1969, while having to deal with Loyalists who feared that bilingualism would undermine traditional monarchist values and reduce the power of the Anglophone majority. ${ }^{7}$

Given that 40 per cent of the population of Moncton was French-speaking, ${ }^{8}$ it would have been reasonable to assume that French-language services were offered to the Francophone residents of the city; however, such was not the case in the 1960s. In response, students and other activists demonstrated in 1968 to defend their language and cultural rights and to turn back the tide of assimilation. 
Québec's Quiet Revolution had spread to Acadie. Thanks to Michel Brault and Pierre Perrault, the events of 1968 were documented in the film, L'Acadie, l'Acadie?!?. Repeated requests from Francophone groups finally prompted Moncton city council to start looking into the issue of French language services after 1968. Yet equality was still a dream in 1972. In January of that year, when l'Acadie, l'Acadie ?!? was aired on Radio-Canada, tensions between the language groups were revived, sparking renewed unrest. Despite Moncton Mayor Jones's vocal intolerance and refusal to offer translation services, a majority of Acadians did not quietly submit to self-translation into English. They understood that Jones's position on translation was grounded in his desire to see Acadians quietly assimilate into the dominant English culture through self-translation. They also knew that the key to improved communication between the two language groups was increased bilingualism on the part of Anglophones. The equality of the province's two linguistic communities was voted into law by the Hatfield government in 1981, and Law 88 entrenched into the Canadian Constitution in 1993 at the request of New Brunswick's Frank McKenna, after the latter bowed to pressure from the Acadian community (see Musée acadien, on line).

\section{"A Cry to Fend off Death"?: Resistance Through Untranslated Poetry}

Nationalist poetry ${ }^{10}$ written by Acadians during the 1960s and especially during the 1970 s clearly articulated the concerns that the students voiced to Moncton city councillors in 1968. A number of important collections of poetry was published in the 1970s, the most notable of which is arguably Raymond Guy LeBlanc's Cri de terre (1972), the newly founded publisher Les Éditions d'Acadie's first publication. Two additional collections of poetry that exemplified Acadian nationalism ${ }^{11}$ were also published by Les Éditions d'Acadie in the early 1970s: Guy Arsenault's Acadie Rock (1973) and Herménégilde Chiasson's Mourir à Scoudouc (1974). These poets contributed actively to the Acadian Renaissance (Boudreau 1990: xix). Like their Québec counterparts, for example Jacques Godbout, they decried one-sided bilingualism that more 
often than not resulted in identity disintegration and, eventually, assimilation.

In "La poésie acadienne : entre esthétique de l'hybridité et intraduisibilité" [Acadian Poetry: between an aesthetics of hybridity and untranslatibility], Jean-Guy Mboudjeke examines the anguish expressed by Acadian poets in and through their bilingual verse. While he refers to this verse as hybrid because of the cohabitation of two languages, generally speaking the distinction is made between hybrid languages that result from interlinguistic interference (e.g., Chiac or Joual) and bilingual verse that plays aesthetically with plurilingualism. Mboudjeke examines poetry that combines dominated and dominant languages in such as way that the verse cannot be translated into English without sacrificing to a large extent the expression of sociolinguistic angst. Many Francophone Acadians wished to be able to live an existence that was closer to the monocultural and unilingual reality that their forefathers and foremothers had lived and that the vast majority of their Anglophone compatriots were living. Doing so would have freed them from having to translate themselves constantly. Mboudjeke explores the demoralizing and alarming impact of assimilation on the Acadian psyche in the 1970s, as well as the perceived danger of a hybrid language, nonetheless appreciated for its aesthetic qualities. He takes as a case in point Jean Fraterne's bilingual, rather than linguistically hybrid, poem, "Voilà mon pays", ${ }^{12}$ which describes the sociolinguistic, bilingual, reality with which Acadians were forced to deal on a daily basis. At the outset, the poet refers optimistically to the spirit of bilingualism that was intended to unite Canada's two charter language groups and put them on an equal socio-linguistic footing (Fraterne, in Mboudjeke 2008: 89):

Deux langues, un coeur,

Two languages, one heart [literal translation of preceding line],

Voilà mon pays [This is my country ${ }^{13}$ ]

Bilinguisme et biculturalisme

Bilingualism and biculturalism [literal translation of preceding line] 
However, hard reality quickly rids the poet of his idealistic illusions. Only Francophones are bilingual; they speak in English to the Anglophone majority at work and in social settings. French in the end is very rarely used:

On parle uniquement en anglais. [People speak in English only.]

Tout se passe en anglais! [Everything takes place in English!]

Est-ce que je me suis trompé ? [Was I mistaken?]

Ma langue s'en va en fumée ! [My language is going up in smoke!]

Oops ! Correction! One language, no heart, Voilà mon pays ! [That's my country!]

Fraterne's bilingual poem is an example, at least to some extent, of self-translation. Should it be translated exclusively into English, it would become a unilingual poem written in the dominant language and, as such, would give the illusion that "the sourcelanguage text [was] written in the target language, overlooking the differences in culture [...] and in linguistic structure" (Meschonnic and Pym 2003: 341).

In his bilingual prose poem "Jaune", ${ }^{14}$ Herménégilde Chiasson explores the source of the socio-linguistic problem, and lays it squarely on the shoulders of patronizing Anglophones and those Acadians who submit body prostrate to the unilingualist position of the dominant culture (in Mboudjeke 2008: 91):

PLEASE PLEASE PLEASE please kill us [...] please treat us like shit please, le premier mot que nous apprenons à leur dire et le dernier que nous leur dirons please [the first word that we learn to say to them and the last one that we will say is please]. Please, make us a beautiful ghetto, not in a territory, no, no, right in us, [...]. Nous fondons comme une roche à la chaleur de l'indifférence de la tolérance de la diplomatie du bilinguisme $[\ldots]$ de l'aplatventrisme chronique $[\ldots][\mathrm{We}$ 
melt like a rock from the heat of indifference of the tolerance of the diplomacy of bilingualism [...] of chronic servility].

As our glosses clearly show, the French words of Chiasson's poem can be translated. However, again, the cost of a unilingual English translation would be high, for the result would be an example of annexation. Yet, while both Fraterne's and Chiasson's poems are bilingual and invite a reflection on the translation of bilingual texts, they are not true examples of a hybrid language such as Chiac (see sections on LeBlanc and Daigle).

It is, nevertheless, clear that literary creations written to express feelings of linguistic tensions resulting from bilingualism can pose challenging transfer problems when it comes to translating them for members of another language group. As Mboudjeke convincingly argues, the compromised "translatability" of Fraterne's and Chiasson's poetry into English, the language of the dominant, threatening group, represents an inherent danger. When translating a bilingual text into the dominant language that is one of its constituent elements, the socio-linguistic tensions between dominant and dominated language groups are more often than not attenuated in translation. It is interesting to note that a bilingual New Brunswicker residing in Fredericton and a poet in his own right, Fred Cogswell, published translations of Acadian poetry in literary journals such as Canadian Literature in the 1970s, ${ }^{15}$ and he seemingly deliberately chose to concentrate on poems written in "standard" Acadian French and to translate them into standard English. It is noteworthy that the bilingual poems referred to above are not on the list of the works that he translated.

\section{Antonine Maillet}

Since the late 1980s, Antonine Maillet has successfully translated a number of theatre plays, especially those of William Shakespeare. ${ }^{16}$ Nevertheless she is primarily known for her accomplishments as a novelist and a playwright. Les Crasseux (1968) is the first play that she wrote in Acadian, and $L a$ 
Sagouine (1971), also written in Acadian, brought her international acclaim. Her novel Pélagie-la-Charette (1979) earned her the prestigious Prix Goncourt.

From the beginning of the Quiet Revolution, Québécois and Acadians have fought not only for the right to express themselves in the public arena, but also to express themselves in their own language. Maillet chose to write in a distinctively Acadian voice and managed to give a literary form to an oral literature with ties to the seventeenth century in her desire to have acknowledged the nobility of old or outdated words that were little used and understood (Courchene 1992: 69). Evelyn Dumas describes the importance of Maillet's use of the Acadian language in her article "Language can be the best revenge", published in Montréal's The Gazette on 13 February 1982:

As in [Antonine Maillet's] previous books set in Acadia, the main character [...] is language. [...] One would be tempted to call it [Acadian] archaic, were it not that in France, the French find Maillet's literary Acadian easier to understand than Michel Tremblay's Québécois. [...] No wonder such an unexpected explosion in French literature has the power to make other French-speaking communities sit up and take notice of a people long forced into silence.

Maillet's work displays to full effect Acadian traditions through her rich vocabulary and picturesque expressions used by Francophones from the Atlantic provinces. ${ }^{17}$ The "fanatical defender" (Maillet 1999: 52) of Acadian French found her inspiration in the writings of sixteenth- and seventeenth-century canonical writers, such as, Rabelais, Perrault and Molière. During an interview with Margaret Courchene, Maillet expressed her hope that her use of language would put vernacular "Acadian" French into the realm of art (Courchene 1992: 69). The Acadian woman of letters would soon identify the horizon of expectation of her readers who had a growing interest in the use of all levels of language, including 
popular varieties of Canadian French, that a reader of Perrault or Molière could understand, but also a speaker of rural Acadian, whose French is reminiscent of Rabelais's, as Maillet's dissertation had concluded. ${ }^{18}$ Maillet rejected limiting her language to the purist, standard French approved by the French "Académie", thereby, affirming that Acadie's renaissance was to discover that Acadians were a people who had its own language (Ibid.: 68), an affirmation that echoed Québec's sovereigntist discourse. ${ }^{19}$

According to Annie Brisset, 1968 inaugurated the use of a Québec sociolect as a language of English-French translation in Québec (Brisset 1990: 34). Luis de Céspedes translated La Sagouine from Acadian French into English in 1979 and made every effort to use a register equivalent to the source-text sociolect by resorting to regional and popular varieties of Canadian English. He made a sincere effort to reproduce the popular and rural oral style ("sayin", "hit'm") and the humoristic tone of the original. When the same pronunciation or syntax cannot be reproduced, the translator compensated elsewhere in the sentence. For example, the pronunciation of "coument [comment]" (1971: 95) is rendered by "fer" (1979: 111) and "Coument mort qu'il était lors de sa première mort,ça..." (1971: 95) by "How dead he was when he died fer the first time, well" (1979: 111). The translator thus attempted to reproduce the source text's sociolect, as well as sociocultural details such as poverty ("il puait toute sa vie" (1971: 96) /"he'd been stinkin all his life" (1979: 112)) and Catholicism ("asseyait de se désentortiller les doigts de son chapelet" (1971: 96)/"tryin to free his fingers fr'm his rosary" (1979: 112)), so that Anglophones who read the translation would come as close as possible to understanding the message of the original. However, what was lost, at least to some degree, in the translation was the savoury language (old verb forms such as "avont [avaient]" and pronunciation such as "cimetchére" (1971: 95) [cimetière]). Nevertheless, the themes of Acadian poverty, the importance of family lineage (Antoine à Calixte), and the conflict between those who dominate (the Acadian elite, Anglophones) and the 
dominated (e.g., the washerwoman la Sagouine) are clearly understood in de Céspedes's English translation. It is fair to say that his effort to reproduce the Acadian sociolect was relatively successful, and that the translation was not aseptic. While this translation cannot be considered successful " $[d]$ ecentring" because "the linguistic structure of the [source] language-system" does not become "value within the system of the text" (Meschonnic and Pym 2003: 341), neither is it "annexation" (idid.) in that cultural difference has been successfully transferred.

\section{Raymond Guy LeBlanc}

Raymond (Guy) LeBlanc's Cri de Terre (1972, revised editions 1986, 1992) was Les Éditions d'Acadie's first publication. His poetry announced a literature of revolt in search of a country. ${ }^{20}$ He feared that if Acadians did not soon wake up to the dangers of assimilation, they would disappear (see Jacquot, n.d.). A social activist, he was conscious of his role as one of a group of Acadian intellectuals who wished to become embodied agents for social change (Belliveau 1992: 76-77). Jean-Paul Hautecoeur explains that young left-wing Acadians of the 1970s demanded not only the right to speak, but also the right to linguistic and social self-determination (in Belliveau 1992: 77).

LeBlanc's poem "Je suis Acadien" was first published in 1972 in Cri de terre, an example of militant poetry (see Arcand et al, 1972). The poem presents the power relationship between dominant Anglophones and dominated Francophones. His view of language contact is diglossic, the product of a conflictual relationship between French and English, which results in the fragmentation of the bilingual individual's identity. Fred Cogswell and Jo-Anne Elder translated the poem and included it in Unfinished Dreams (1990). An essay signed by Université de Moncton Professor Raoul Boudreau introduces the collection of poetry in translation. 
LeBlanc's anger is visceral in "Je suis Acadien", a linguistically hybrid poem, although a far cry from the hybridity of twenty-first-century Chiac. The first two lines vehemently denounce the insinuation of English into the most emotional areas of personal expression: "Je jure en anglais tous mes goddams de bâtard/Et souvent les fuck it me remontent à la gorge" (LeBlanc 1992 [1972]: 65) translated as "I curse in English every mongrel goddamn in the book/And fuck-its often stick in my throat (Cogswell and Elder 1990: 121. Note that the translators italicised words in their translation that were written in English in the original.). LeBlanc concludes his poem in anguish:

Je suis acadien [I am Acadian]

Ce qui signifie [Which means]

Multiplié fourré dispersé acheté aliéné vendu révolté [Stuffed dispersed bought alienated sold out rebellious./A here there and everywhere]

Homme déchiré vers l'avenir [Man torn open towards the future] (LeBlanc op. cit./Cogswell and Elder op. cit.)

This passionate and powerful poem evokes the existential agony of an Acadian who feels that he has no country, no language, and who imitates Anglophone upstarts, while waiting for them to bury him and his people. The poem is raw, the poet's nerves are exposed. LeBlanc uses English swear words, a productive linguistic phenomenon in Southeast New Brunswick that is marked by the dominant language's swear words being inserted into the minority language: "goddams de bâtard", "fuck $i t$ " and the invocation of the Lord in English, "Jesus Christ" (Kasparian and Gérin 2005: 130). The English words are not set off from the French words in LeBlanc's poem; rather they are integrated into the Acadian expressivity of Southeast New Brunswick: this is an example of the local language called Chiac.

The translation reproduces very closely the meaning of the original, while transferring certain English words from the original poem to the translation. These English words have been marked by italics in translation (as noted above), the strategy 
retained by the translators. However, the swear words and other English words incorporated into Chiac have a different emotional charge than when the same words are used by Anglophones. The translators" compensation strategy of putting the "foreign Chiac" words in italics: "goddamn, fuck-its, christs, windshield, mediumrare, tabernacles, hosties, Chrysler, guy, runs me over, cross the street" risks simply confusing unilingual English readers, who would ask themselves why the words are in italics. In fact, the only French word in the list is "hosties" [consecrated bread/wafer, host]. The word "tabernacle" exists in English, although it is rarely used in the plural. Moreover, many Anglophones are not aware that "tabernacles" and "hosties" are Québec swear words. In short, the emotional charge of the original poem has been diluted in English. The profound disillusionment and anxiety felt by the poem's "I" is less visceral in English.

Yet, it must be acknowledged that the translators are faced with a formidable sociolinguistic constraint, which is that of the poem's linguistic hybridisation. And this constraint is very difficult to overcome. It would be necessary to reproduce the same tension between a dominant colonial culture and a dominated colonised culture, but in a language comprehensible to unilingual Anglophones (or to those who do not master French). However, in Canada the receiving culture is the dominant culture, which is, at present, experiencing a colonial relationship primarily with countries that are also English-speaking. So reproducing the same socio-linguistic tensions would be very difficult, if not impossible to recreate. Consequently, the translation has, despite the best intentions of the translators, been centred. $^{21}$ Because the source text has moved from a twolanguage culture to a primarily unilingual system (or to one in which "French" is largely absent) through translation, the hybrid structure of the source-language system does not become a value that "decentres" (Meschonnic and Pym 2003: 341); the source system is not appreciated by the reader of the translation as fundamentally different. 


\section{Gérald Leblanc}

Gérald Leblanc was one of the most prolific Acadian writers whose works, especially his poetry, have been published in Acadie, Québec, France, Belgium and Mexico. He dedicated his first collection of poems, Comme un otage au quotidien, to Raymond LeBlanc. Equal parts Acadian and North American, Leblanc explored the roots of his Acadian identity from many directions. The growing interest in his poetry puts him at the top of the list, along with Herménégilde Chiasson, of modern Acadian poets. A literary activist, he worked on all fronts to stimulate and make known the new voices of Acadian culture. He also wrote lyrics for the Acadian musical group $1755 .^{22}$ Moncton Mantra (1997), his only novel, was translated by Jo-Anne Elder in 2001.

In Moncton Mantra, the narrator expresses himself in standard "Canadian" French that is relatively free of English influence. Whereas the novel defends Chiac and the author sings the praises of the hybrid language in it as he does elsewhere, Leblanc rarely uses it. Chantal Richard explains that despite his stated desire to mix standard French with old Acadian French peppered with English, Leblanc ends up choosing standard French (Richard 1998: 33). In fact, although he inserts québécismes in his novel, in one passage he seems to defend standard French to the point of excluding any and all English interference, transforming English into "foreign sounds" (1997:48). In short, the translation of this novel provides relatively few translation difficulties (from a sociolinguistic point of view). Generally, the translated passages communicate well, though not literally, the meaning of the original passages. For example, when referring to English as "un bruit autre [an other/different noise]" (Leblanc 1997: 48), the translation becomes "foreign sounds" (Leblanc 2001: 41). The language level is formal in both the original and its translation. Nevertheless, the source text is not without translation problems that are more difficult to solve, and the success of the translation is inconsistent. For example, "J'entendis: 'Teint naque sein, çâ vient de quel coin dzu Québèèèèc? Dzu bâs dzu Fleuve?” (Leblanc 1997: 97) is rendered 
well by the adaptation: "That wasn't exactly what I heard, of course, because his accent was very strong" (Leblanc 2001: 95). The adaptation of the next example is less successful, but acceptable: "Chez nous, on a de la neige le treize. Ici, vous avez de la naÿze le trä̈ze. Tu sais, une variante sur la même toune. C'est un accent (Leblanc 1997)" translated by: "Down home, we get snow on the fifteenth, here it snows hard in the middle of the month. Six of one, a half dozen of another, whatever accent you have. Variations on a tune" (Leblanc 2001). The reader could ask herself whether "six of one, a half dozen of another" was necessary. Furthermore, the savoury Québécois accent ("aÿ") has been lost; Québec and Acadian vernacular, for example: "icitte [ici], deboute [debout], itou [aussi]", simply disappear in translation. Yet again, the translator is faced with a linguistic constraint; instead of opting for a strategy that would introduce new discursive models into the target system in order to destabilise its complacency, the translator, while not retaining a strategy of annexation does not make a concerted effort to decentre. Furthermore, the editor chose a book cover illustration that served to reproduce Anglophone stereotypes of Acadie, thereby betraying the purpose of Leblanc's book that was to move beyond representations of a rural and maritime Acadie that had to some extent been perpetuated by Maillet's fiction. Leblanc's urban Acadie is in no way conveyed by the book's cover of a young man wearing a peacoat jacket, a gold star (our Lady of Assomption) on his cap, with as a backdrop an isolated house on the beach at Cap Pelé or Shédiac (Leclerc 2005).

\section{France Daigle}

France Daigle is the author of numerous novels. She narrates in standard French; however, some of her characters speak a local vernacular, Chiac, the third language, according to some linguists, of Southeast New Brunswick, after English and French. Compared to Daigle's Un fin passage (2001), the use of Chiac, has increased dramatically in Petites difficultés d'existence (2002), in part, because the novel takes place explicitly in Moncton, where English and French are in constant contact. Erasing Moncton and its local speech 
is not an option in this novel. Rather the couple, Terry and Carmen, speak in Chiac. This is the sole literary work considered in the context of this study that deals explicitly with a hybrid language. Translating it presents different challenges from those presented by the translation of Fraterne's and Chiasson's bilingual poems for, in Chiac, the linguistic structures of French have been modified as a result of repeated contact with English. Marie-Ève Perrot (1995) explains that Chiac has a French matrix and a vocabulary that is peppered with English. However, the degree of Anglicisation is variable, and often depends on the communication situation of the speaker.

Robert Majzels' English translation, Life's Little Difficulties (2004), reproduces with great delicacy the main characters' Carmen and especially Terry - voyage of self-discovery through language. Majzels managed to make real for the English reader the emotional reaction of a young Acadian couple to the dangers of assimilation. Moreover, he innovated on a translation strategy level. Traditionally, translators negotiate between two "national" languages for example Antonine Maillet's "Rabelaisian French" could be likened to "Shakespearean English" (Merkle 2000). However, Majzels was presented with a localised linguistic phenomenon, for Daigle creatively has her characters speak a hybrid language that has no socio-cultural equivalent in English Canada (i.e., the same degree of interlinguistic penetration between French the dominant language and English the dominated language). In an effort to compensate, Majzels invented a sort of English Chiac (Leclerc 2008) that, while more timid than its Acadian counterpart, nevertheless represents a laudable minoritising initiative (Venuti 1998) that serves to decentre the translation, at least to some extent, in the target culture. For example, the following excerpt is taken from Majzels' translation of Daigle's Chiac: "On purpose? Moi?", "Reliure à pince. I know. That's what's si great. Toutes ces choses we didn't know the names for" (Daigle 2004: 136). In this short example, the following words are French: "moi" [me], "reliure à pince" [clip binder], "si" [so], "toutes ces choses" ]all those things]. However, it cannot be taken for granted that a Canadian Anglophone will understand them. As such, the linguistic structure of the source text (especially "reliure à pince" [lit. binder with clip]) has 
penetrated, even if modestly, the language system of the target text. Anglophones who do not immediately understand what they are reading will, at the very least, be shaken from their habitual linguistic complacency. This is a successful attempt at "[d]ecentring" (Meschonnic and Pym 2003: 341), despite Majzels' timid use of hybridity in the translation.

\section{Multilingualism and translation: From the margins to the centre ... and back ... through minoritising translation}

Since the 1970s, Acadians have been actively and visibly seeking greater recognition for their linguistic and cultural otherness in the aim of ensuring their long-term survival as a francophone nation. They have given themselves a unique polyphonous voice old Acadian, Chiac, standard Canadian French, English -, and express themselves publicly in this voice both on the political and on the cultural scene. Some choose to express themselves in standard Canadian French, whereas others opt for the local varieties of Chiac and Acadian French. Those who choose a local variety seek to set themselves apart from the other francophone groups of Canada, especially, the Québécois, as well as from the French. We have seen examples of these linguistic varieties in the source texts examined in the context of this study.

The first Acadian writer to stand out internationally and to interact with an international audience was Antonine Maillet, who minimises the use of English in her writings. The other writers in translation also enjoy a certain degree of international acclaim, and their recourse to English, or Chiac for that matter, varies. On the one hand, Raymond LeBlanc communicates the dangerous omnipresence of English on Acadian territory in his poems that occasionally integrate English words. On the other hand, while singing the praises of Chiac in some of his writings, Gérald Leblanc in fact makes very little use of it. For her part, France Daigle narrates in standard French and her recurring characters, Carmen and Terry, speak in Chiac in her more recent novels. However, as new parents, Carmen and Terry question their use of the hybrid language, out of concern 
for their children's cultural and linguistic survival. The way linguistic hybridity is dealt with in these Acadian literary works seem to betray a conflicted attitude towards hybrid varieties of French.

So how have the translators working into English dealt with the soul searching, both linguistic and identitary, that is so integral a part of the Acadian literary products we have considered here? First, it must be recalled that the translators are (to varying degrees multicultural) Canadians and produce numerous literary translations. They translate out of a love of literature and a commitment to the charter ideals (bilingualism and biculturalism) of their multicultural country. Their translation products testify to their attempt to maximise linguistic and cultural transfer, while negotiating the linguistic constraints that mark the transfer from the linguistic varieties of the source minority culture to the linguistic varieties of the target majority culture. As we have seen, the difficulties related to linguistic transfer are formidable, however no less so than the difficulties encountered by a minority people who must fight the homogeneous effects of globalisation expressed through English that is also and usually the dominant language with which they must grapple on a daily basis. While it is perhaps possible to identify weaknesses in the translations, literary translators are often the first to acknowledge that a literary text can grow through retranslation. Nevertheless, we can affirm that J.-A. Elder (Moncton Mantra) and R. Majzels (Life's Little Difficulties) generally avoided ethnographic and assimilating translation strategies (Leclerc 2005: 178) and that the translations produced by L. de Céspedes (La Sagouine) and F. Cogswell/J.-A. Elder ("I am Acadian") attest to the best of intercultural and transcultural intentions through translation, in addition to literary sensitivity. Whether the English translation is perfect or not, highly successful or not, ${ }^{23}$ in all cases the translators appreciate the cultural other's alterity and, as a result, at the very least attempt to introduce the dominant culture to the very difficult existence with which Acadians, like Canada's other minor francophone communities, must deal on a daily basis to ensure their linguistic and cultural survival. The fact remains that the only clear effort at horizontal translation between two "equal" minor cultures was made by Majzels, for the other translations, likely 
unintentionally, reproduce more traditional vertical power relations (Merkle and Klimkiewicz 2008). ${ }^{24}$

To sum up, the study of selected passages of a few translated Acadian works has given us insights into the heavy weight of a fragile identity on the psyche of a minority population. The clearest example of the schizophrenic angst of a fractured identity being diluted in translation is LeBlanc's "I am Acadian". By contrast, Majzels' choice of a minoritising translation strategy may certainly contribute to decentring dominant culture complacency, provided, of course, that the hybrid translation is read.

\section{Notes}

1. For a discussion of Acadian French, see below the section on Antonine Maillet.

2. M.-È. Perrot (1995) explains that Chiac has a French matrix and a vocabulary that is peppered with English. However, the degree of Anglicisation is variable, and often depends on the communication situation of the speaker.

3. See Deleuze and Guattari (1975), and F. Paré (1994 and 2003).

4. On the reasons for refusal of translation on the part of minor cultures, see R. Meylaerts, forthcoming.

5. Dieppe, Moncton and Riverview make up Greater Moncton. Bouctouche is a 30-minute northbound drive from Moncton along the coast of the Northumberland Strait.

6. Les Éditions d'Acadie would go bankrupt in 2000.

7. For more information, see Durand, 2.1, "Milieu politique".

8. Figure cited by students during their presentation to his Worship Jones in Michel Brault and Pierre Perrault's L'Acadie, l'Acadie ?!?.

9. Raoul Boudreau, 1990: xix. 
10. For information on Acadian as well as other Canadian literature in translation see: Stratford and Newman (1975), White (2008), White et al (forthcoming).

11. The Parti acadien existed between 1972 and 1982 and was founded in Northeast New Brunswick (la Péninsule acadienne), a region that was noticeably poorer than the "golden triangle" of southern New Brunswick (Fredericton, St. John, Moncton). Its first leader was Euclide Chiasson. The party's goal was to create an autonomous Acadian province.

12. First published in Runte et al 1979: 111.

13. Unless otherwise stated, the translations are ours.

14. First published in Chiasson 1974: 44.

15. The following is a partial list of Acadian poetry first translated by Fred Cogswell in the 1970s and published in Canadian Literature (1976, numbers 68-69), sometimes under different names: Guy Arsenault: "To Celebrate September", "The Wharf"; Herménégilde Chiasson: "Between the Season of Extravagant Love and the Season of Raspberries", "All the King's Horses"; Ronald Després: "Hymn to Spring", "I Loved You", "I Thought of You All Day"; Léonard Forest: "And I Dreamed of a Great Black Sun"; Raymond Guy LeBlanc: "Winter", "Land-cry".

16. See Merkle 2000 and 2008.

17. For a discussion of Maillet's literary language and problems of translation, see Stratford (1986).

18. Rabelais et les traditions populaires en Acadie, Québec, Presses de l'Université Laval, 1971.

19. Whereas a growing number of Acadian writers make use of a hybrid language, Moncton's Chiac, in their writings (J. Babineau, G. Leblanc, F. Daigle), Maillet writes in French and in Acadian.

20. In addition, other Acadian poets have voiced the need for revolt: G. Arsenault's Acadie Rock (1973), H. Chiasson's Mourir à 
Scoudouc (1974), C. Duguay's Les Stigmates du silence (1975), U. Landry's Tabous aux épines de sang (1977), among others.

21. A non linguistic solution would be to publish a bilingual edition and to annotate carefully and completely both the original poem and the facing translation.

22. The year 1755 is highly significant in Acadian history, for it is the year that marks the Grand Dérangement, which in reality occurred for the most part from 1750-1756.

23. See Koustas (2008: 396): "Lee Skallerup: In response to the idea of 'policing' the translations of our literature, I would strongly disagree. Certainly the French translation of Barney's Version done in France was horrible from a Québécois perspective, but it was perfect, so to speak, for the audience in France. [...] We have to be careful about this idea of limiting and controlling how our literature is distributed. [...] one can venture that the massive success of Le Monde de Barney played a significant role in the publisher's decision to commission a new, chez eux, translation of the novel".

24. Teresa Tomaszkiewicz has guided the voyage of discovery of Acadian and other minor Canadian francophone literature in Poland, a country that enjoys minority status within the European Union. Her masters' students at Adam Mickiewicz University in Poznań have translated a number of works into Polish. Teresa Tomaszkiewicz, Aurelia Klimkiewicz and Alicja Żuchelkowska have edited and recently published (2009) the first anthology of minor Canadian francophone literature in Polish translation (Antologia wspótczesnej literatury Kanady frankofońskiej published by Oficyna Wydawnicza Leksem, Łask).

\section{Works Cited}

Arcand, P.-A., et al. 1972. "Une poésie militante". Revue de l'Université de Moncton, 5, 1, 96-118. 
Belliveau, M. 1992. “Analyse critique”. In Cri de terre: poèmes. Moncton: Éditions d' Acadie, 69-91.

Bhabha, H. 1994. The Location of Culture. London and New York: Routledge.

Boudreau, R. 1990. "Poetry as Action". In Unfinished Dreams. Fredericton: Goose Lane Books, xvii-xxvii.

Brault, M. and P. Perrault. 1971. L'Acadie, l'Acadie ?!?. Ottawa: Office national du film. [On line] http://www.onf.ca/film/Acadie_Acadie/

Brisset, A. 1990. Sociocritique de la traduction: théâtre et altérité au Québec (1968-1988). Longueil : Éditions du Préambule.

Chiasson, H. 1974. Mourir à Scoudouc. Moncton: Éditions d'Acadie.

Cogswell, F. and J.-A. Elder, eds. and trans. 1990. Unfinished Dreams. Fredericton: Goose Lane Books.

Courchene, M. 1992. "Mieux est de ris que de larmes écrire': entretien avec Antonine Maillet". Revue Frontenac: littérature acadienne, 9, 64-79.

Daigle, F. 2001. Un fin passage. Montréal: Les Éditions du Boréal.

Daigle, F. 2002. Les petites difficultés d'existence. Montréal: Les Éditions du Boréal.

Daigle, F. 2004. Life's Little Difficulties. Trans. Robert Majzels. Toronto: House of Anansi Press.

Deleuze, G. and F. Guattari. 1975. Kafka, Pour une littérature mineure. Paris: Éditions de minuit.

Dumas, E. 1986. "Language Can Be the Best Revenge". Dossier de presse 1972-1986. 
Sherbrooke: Bibliothèque du séminaire de Sherbrooke, n.p.

Durand, M. 2004. "Chapitre II. Le temps des réformes et des revendications sociales: 1960-1980". In Évolution et consolidation de l'espace francophone du Grand Moncton au Nouveau-Brunswick: 1960-2002. Québec: Université Laval.

Godbout, J. 1964. "Les mots tuent". Liberté, 6/2, 139-143.

Jacquot, M. n. d. "Écrire dans l'Acadie d'hier et d'aujourd'hui". In Bibliographie des études comparées des littératures canadienne, québécoise et étrangère de l'Université de Sherbrooke. [On line]

http://compcanlit.usherbrooke.ca/liens.html\#regionales; http://ecrits-vains.com/points_de_vue/martine_jacquot5.htm

Kasparian, S. and P. Gérin. 2005. "Une forme de purification de la langue: étude des jurons et des gros mots chez des minoritaires francophones, le cas des Acadiens". Francophonies d'Amérique, 19, 125-138.

Koustas, J. 2008. "Round Table Discussion: Literary Translations and Linguistic Diversity - Canadian Literature on the International Scene". In Traduire depuis les marges/Translating from the Margin, ed. D. Merkle, J. Koustas, G. Nichols and S. Simon. Québec: Nota bene, 387-400.

Leblanc, G. 1981. Comme un otage au quotidien. Moncton: Les Éditions Perce-Neige.

Leblanc, G. 1997. Moncton Mantra. Moncton: Les Éditions PerceNeige.

Leblanc, G. 2001. Moncton Mantra. Trans. J.-A. Elder. Toronto: Guernica. 
LeBlanc, R. G. 1992 [1972]. Cri de terre Poèmes 1972. P. l'Hérault, preface; M. Belliveau, critical analysis. Moncton: Éditions d'Acadie. Third revised edition.

Leclerc, C. 2005. "Between French and English, Between Ethnography and Assimilation: Strategies for Translating Moncton's Acadian Vernacular". TTR, XVIII/2, 162-192.

Leclerc, C. 2008. "Le Chiac, le Yi King, et l'entrecroisement des marges: Petites difficultés d'existence en traduction". In Traduire depuis les marges/Translating from the Margin, ed. D. Merkle, J. Koustas, G. Nichols and S. Simon. Québec: Nota bene, 163-192.

Maillet, A. 1971. La Sagouine. Montréal: Éditions Leméac.

Maillet, A. 1979a. Pélagie-la-Charrette. Montréal: Éditions Leméac.

Maillet, A. 1979b. La Sagouine. Trans. L. de Céspedes. Toronto: Simon \& Pierre.

Maillet, A. 1982. Pélagie. Trans. Philip Stratford. New York and Toronto: Doubleday.

Reprinted in 2004 as Pélagie. The Return to Acadie. Fredericton: Goose Lane Editions.

Maillet, A. (1999). Chronique d'une sorcière de vent. Montréal: Éditions Leméac.

Mboudjeke, J.-G. 2008. "La poésie acadienne: entre esthétique de l'hybridité et introaduisibilité". In Traduire depuis les marges/Translating from the Margins, ed. D. Merkle, J. Koustas, G. Nichols and S. Simon. Québec: Nota bene, 7592.

Merkle, D. 2000. "Antonine Maillet, femme de théâtre et traductrice de Shakepeare". In L'Acadie au féminin: Un 
regard interdisciplinaire sur les Acadiennes et les Cadiennes, ed. M. Basque, et al. Moncton: Chaire d'études acadiennes, 267-293.

Merkle, D. 2008. "Translation Constraints and the 'Sociological Turn' in Literary Translation Studies". In Beyond Descriptive Translation Studies. Investigations in Homage to Gideon Toury, ed. A. Pym, M. Shlesinger, D. Simeoni. Philadelphia and Amsterdam: John Benjamins, 175-186.

Merkle, D. and A. Klimkiewicz. 2008. "Présentation du numéro: La traduction verticale ou horizontale? Entre langues et cultures en 'mode mineur'". Alternative francophone: Pour une francophonie en mode mineur I/1. [Online] http://ejournals.library.ualberta.ca/ index.php/af/issue/current

Meschonnic, H. 1973. Pour la poétique II. Paris: Gallimard.

Meschonnic, H. (author) and A. Pym (introduction and translation). 2003. "Texts on Translation". Target, 15/2, 337-354.

Meylaerts, R. (forthcoming). "Les relations littéraires au-delà des oppositions binaires: national et international, traduit et non traduit". TTR, XXVVII/2.Musée acadien, Université de Moncton. n.d. "Histoire acadienne: La nouvelle Acadie". [On line]

http://www2.umoncton.ca/cfdocs/etudacad/maum/index.cfm ?page $=$ nouvelle $\&$ section $=$ histoire

Paré, F. 1994 [1992]. Les littératures de l'exiguité. Ottawa: Éditions du Nordir.

Paré, F. 2003. La distance habitée. Ottawa: Éditions du Nordir. 
Perrot, M.-È. 1995. “Aspects fondamentaux du métissage français/anglais dans le chiac de Moncton (NouveauBrunswick)" [unpublished doctoral dissertation]. Paris: Université de la Sorbonne nouvelle.

Pratt, M. L. 2007 [1992]. Imperial Eyes: Travel Writing and Transculturation. London and New York: Routledge. Second edition, revised and expanded.

Richard, C. 1998. "La problématique de la langue dans la forme et le contenu de deux romans plurilingues acadiens: Bloupe de Jean Babineau et Moncton Mantra de Gérald Leblanc". Studies in Canadian Literature/Études en littérature canadienne 23/2, 19-35.

Runte, H.R., J. Chiasson and N. LeVert, eds. 1979. Plumes d'icitte: la première Acadie s'exprime. Yarmouth: Imprimerie Lescarbot.

Simon, S. 1999. Hybridité culturelle. Montréal: Île de la tortue.

Stratford, P. 1986. “Translating Antonine Maillet's Fiction”. Québec Studies, 4, 326-332.

Stratford, P. and M. Newman. 1975. Bibliography of Canadian Books in Translation: French to English and English to French. Bibliographie de livres canadiens traduits de l'anglais au français et du français à l'anglais. Ottawa: Committee on Translation, Humanities Research Council of Canada.

Venuti, L. 1998. The Scandals of Translation. Towards an Ethics of Difference. London and New York: Routledge.

White, M. 2008. La traduction littéraire en Acadie: Sources. Moncton: Institut d'études acadiennes. [On line] 
Francophone Dynamics in a Translated Canada:

From the Margins to the Centre and Back

http://www0.umoncton.ca/iea/Documents/4.B.1-Biblio.000.pdf

White, M., C. Blanchard and J.-A. Noël. Forthcoming, Second edition. Bibliographie de l'Acadie traduit.e. Moncton: Institut d'études acadiennes. 